\title{
"WHAT'S IN THE BOX?" - ARCHIVES, HISTORY SKILLS AND HONOURS STUDENTS
}

\author{
DOI: http://dx.doi.org/10.17159/2223-0386/2020/n23a2
}

Karen L Harris

University of Pretoria

Pretoria, South Africa

karen.harris@up.ac.za

ORCID No: orcid.org/0000-0002-9246-5950

\author{
Ria van der Merwe \\ University of Pretoria \\ Pretoria, South Africa
}

ria.vandermerwe@up.ac.za

\section{Abstract}

Historical thinking skills have become the mantra of the history profession. The aims, objectives and outcomes of history classes and courses at both secondary and tertiary level resonate with the inclusion of the skills of the historian's craft. Primary materials are among the tools included in school teaching packs and university readers to inculcate the research dimension of history coupled to analysis, selection, critical thinking, and logical formulation. In this article we propose to reflect on a recently developed component of a postgraduate Honours module introduced in the Department of Historical and Heritage Studies at the University of Pretoria in collaboration with the University archive. This element involved students engaging with un-inventorised virgin primary documentation emanating from the Museum of the Transvaal Education Department. They were tasked with not only having to critically read the content of the "box", but to sort, appraise and contextualize the documentation. In addition, the brief also required students to consider the research potential of the contents and present their findings at a colloquium entitled "What's in the Box?" We argue that the success of this component of the course took the students one step further in the making of history and thus exposed them to experiential learning and what could be termed the "inner workings" of the historians'craft.

Keywords: Archival documentation; History Honours module; History skills; Historian's craft; Primary documents; Archivists; Experiential teaching.

\section{Introduction}

This article sets out to consider the teaching of history within a postgraduate honours context. It considers the introduction of a new component in a history honours module which we believe adds an innovative dimension to the teaching of the subject by exposing the students to another aspect of the historian's craft, but at the same time has the potential to inspire and intrigue them. The article is divided into three parts: the first "teaching and 
history" reflects very briefly on how the teaching of history has changed and transformed over time. The second part, "archives and history", presents a brief outline of what the module entails and what the new component we have devised involves. It also presents an overview of what the archival theoretical dimension includes and what is presented to the students. The last part, "honours and archives" focuses on the student component of the new section as well as an evaluation of and reflection on their experiences. It concludes by showing how this initiative can be adapted and utilized across the educational spectrum.

\section{Teaching and History}

History teaching in its very broadest sense has had a long trajectory often priding itself as being one of the earliest forms of education. Originating as oral tradition across many cultures, is has developed and transformed from ancient times, through the classical, to the modern and post-modern. ${ }^{1}$ History has at the same time evolved in the manner in which it has been taught. From the very earliest forms of what might even be termed prototype history, the official method used to teach it seems to have taken on a relatively rigid form among societies such as the Mesopotamians, Egyptians, Aztecs and Incas. Rote memorization was often the key in the method of accurate oral repetition. ${ }^{2}$ Historical writing was also evident in the early empires of the Chinese and Islamic societies often predating that of the Western tradition where the first empirical studies became evident. ${ }^{3}$ Yet despite this ancient legacy, history was not initially regarded as a specific subject of instruction at school or university level. ${ }^{4}$ It appears to only have been acknowledged as a separate discipline worthy of study from the sixteenth century onwards when it was introduced to universities. ${ }^{5}$ This has partly been ascribed to the fact that history emerges as part of the wide spectrum of the liberal arts curriculum. It can also be attributed to the fact that because it was so integral to all matters of learning it was not considered as a separate field of study or discipline in its own right -

1 GR Elton, The Practice of History (London, Fontana Press, 1987), pp. 12-13; A Momigliano, "The introduction of teaching History as an aAcademic subject and its implications”, Minerva, 21(1), 1983, p. 1.

2 O Anweiler (et al), Education, Encyclopaedia Britannica (available at: https://www.britannica.com/topic/ education/ Education-in-the-earliest-civilizations, as accessed September 2019).

3 D Woolf, "Historiography", C Horowitz (ed), New Dictionary of the History of Ideas (New York, Scribner, 2005), pp. liv-lix.

4 A Momigliano, "The introduction of teaching History as an academic subject and its implications", Minerva, 21(1), 1983, p. 1.

5 A Momigliano, "The introduction of teaching History as an academic subject and its implications", Minerva, 21(1), 1983, pp. 10-11. 
it was what is now regarded as transdisciplinary. This conundrum aligns with what John Tosh claims to be: "One of the distinguishing features

of the profession is its heated arguments concerning the objectives and limitations of [its] study". ${ }^{6}$

The second half of the $19^{\text {th }}$ century is often regarded as the period that signaled the professionalization of Western history. ${ }^{7}$ Dubbed the founding father of modern history - or more recently "the great transformer" Leopold von Ranke proclaimed that the historian's duty was "first and foremost to relate the past as it actually happened". ${ }^{8}$ Of particular relevance to this discussion was the emphasis placed on the extensive and scientific use of archives and the "particularity of history displayed through the most meticulous and painstaking attention to a single document." "For over two centuries this empirical approach to the study of history has persisted, despite the onslaught of the linguistic turn, postmodernism and other meta-modern schools. ${ }^{10}$ Thus for many historians the archive remains the "epistemological claim to "the truth" 11 and it is for this reason that the subject of this article, "the box", cannot be ignored.

While the content of what has been taught in history has changed dramatically over time, so too have the methods of teaching history. In modern times, history has been revolutionized from a passive talk-andchalk and dates-and-facts formula ${ }^{12}$ to the introduction of a participatory format with active involvement of the learner or student. In other words rather than the learner merely "receiving" history, they are encouraged "to do" history. ${ }^{13}$ This has been achieved through the introduction and

6 J Tosh, The pursuit of History, 5 (London, Longman, 2010), p. ix.

7 D Woolf, "Historiography", MC Horowitz, (ed), New dictionary of the history of ideas, 1 (New York, Scribners, 2005), p. lix.

8 D Woolf, A concise history of History: Global historiography from Aantiquity to the present (Cambridge, Cambridge University Press, 2019), p. 178.

9 D Woolf, A concise history of History: Global historiography from antiquity to the present (Cambridge, Cambridge University Press, 2019), p. 177.

10 K Jenkins, What is History? (London, Routledge. 1995); J Black and DM MacRaild, Studying History, 2 (New York, Palgrave, 2000); RJ Evans, In defence of History (London, Granta Books, 2000), pp. 9-14.

11 Our thanks to the anonymous reviewer of this article for this comment.

12 D Moran, "How history should be taught: Connections to the present", Palo Alto Online, 16 January 2016 (availble at: file://C:/Users/u02549085/Downloads/How\%20history\%20should\%20be\%20taught_\%20Connections\%20 to $\% 20$ the $\% 20$ present $\% 20 \_\% 20 \mathrm{~A} \% 20$ Pragmatist's $\% 20$ Take $\% 20 \_\% 20$ Douglas\%20Moran\%20_\%20Palo\%20 Alto\%20Online\%20_\%20(2).pdf, as accessed August 2019); J Wassermann, "Learning about controversial issues in school History: The experiences of learners in KwaZulu-Natal schools", Journal of Natal and Zulu History, 29(1), p. 131; Study International Staff, "Should we rethink how history is taught in schools?", SI News, 17 May 2019 (available at: https://www.studyinternational.com/news/should-we-rethink-how-history-is-taughtin-schools/, as accessed August 2019).

13 T Haydn (et al), Learning to teach History in secondary school (Routledge, London, 1997), p. 209. 
use of primary source materials being included in the school teaching packs or university readers to bring the learners closer to the realm of history. ${ }^{14}$ From the seventies in the twentieth century "jackdaws" were introduced to provide "an array of fascinating and relevant primary source documents" which were reproduced in their actual sizes for [learners] to touch and explore". ${ }^{15}$ Jackdaws were touted as set to take "students beyond the textbook approach to history" and to "encourage critical thinking and analysis, and augment retention of information". More recently, "primary source kits", "archive units" or "analysis source kits" had a similar intent including the addition of activities and games within the "bundle". ${ }^{16}$ These primary sources include documents, newspapers, artefacts, posters, pictures, films, diaries, photographs and the like. ${ }^{17}$ This in turn often affords the learner the opportunity to be exposed to a wide range of interpretations and perspectives prevalent among the different sources. They are then essentially enabled to see where history comes from and in a sense reconstruct this history from the remnants (resources) of the past.

Aligned to this, is the concerted effort in the more recent history teaching methods to inculcate the skills of the historian's craft which are believed to be imbedded in the discipline. These include the ability to read critically, analyze, select, collate and formulate logically. ${ }^{18}$ These are skills which are believed to be transferable to other subjects and educational domains and therefore have a wide ranging educational value. ${ }^{19}$ These skills need to be applied to the resource material so that they involve an "active and investigatory mode of learning". ${ }^{20}$ This is then what can be termed experiential history as the learner is engaged in the learning process and "learns by doing" and then reflecting on their experiences. ${ }^{21}$ While experiential learning is often aligned to the hard sciences and learners doing hands-on laboratory experiments or practical work, this approach is of a similar nature as the students have a hands-on experience with primary research material.

$14 \mathrm{~J}$ Wassermann, "Learning about controversial issues in school History: The experiences of learners in KwaZulu-Natal schools", Journal of Natal and Zulu History, 29(1), p. 132.

15 Jackdaws Publications (available at: https://www.jackdaw.com/t-jackdaws.aspx, accessed January 2020).

16 RGE Wood, “Archive units for teaching”, Teaching History, 2(6), 1971, pp. 158-165.

17 T Haydn (et al), Learning to teach History in secondary school (Routledge, London, 1997), p. 207.

18 KL Harris, Study guide, Department of Historical and Heritage Studies: Africa and South Africa - An overview, GES 120, 2019, p. 1.

19 RM Manyane, "History teaching in South Africa within the context of the human and social sciences", $\mathrm{PhD}$ Education, Unisa, 1999, pp. 127-141.

20 T Haydn, (et al), Learning to teach History in secondary school (Routledge, London, 1997), p. 208.

21 "Teaching strategies: Experiential learning and field work", Centre for Research and Learning, University of Michigan (available at: http://www.crlt.umich.edu/programs, as accessed January 2020). 
Much of the innovation within the teaching of history is located in the primary and secondary school system. At the tertiary level, the sheer number of students and logistics of lecture halls along with limited lecturing times does not always allow for more innovative and experiential forms of teaching. The undergraduate syllabi are often overladen and thus learning often tends to be mainly "text-based" in digital or analogue formats. ${ }^{22}$ While it can be argued that much can be done on a digital platform in terms of resources, these are often edited or even contrived. There also remains the absence of a real, tactile and haptic experience which handson resources and research provides. It was to address this situation that we developed an element within the honours program to engage the students with the historians' craft beyond what text and documentary resource packs can provide.

\section{Archives and History}

As the honours degree (fourth year following a three-year degree) is seen as a stepping stone between a degree majoring in history and further specialization at masters and doctoral level in history, it is imperative that students are exposed to as many facets of the historian's craft as possible. While it must equip them for independent research that lies ahead, it must also inspire them. This aligns with many of the trends apparent in history teaching at large mentioned above. The honours degree in history in the Department of Historical and Heritage studies (DHHS) at the University of Pretoria subscribes to this view. The course comprises five modules - three of which are core modules, ie. are compulsory and two that are electives, in other words modules of the student's choice. The core modules include: Historiography (GES 701); Theory and Methodology (GES 713) and then the Research Report (GES 770) or extended essay conducted by the student on a topic of their choice.

The GES 713 history honours semester module comprises some 14 themes, some of which are presented by the students in a seminar format.

22 C Behr and S Nevin, "The Roehampton Campus Project: Using campus, collections and memories of the university as a learning and teaching resource for Humanities students", Arts and Humanities in Higher Education, 1(18), 2018, p. 2. 
Table 1: GES 713 Themes $^{23}$

\begin{tabular}{|l|l|}
\hline Theme 1: & Module Introduction \\
\hline Theme 2: & Written documents: Archival Sources \\
\hline Theme 3: & Sources: Written Documents and Working with Archives. \\
\hline Theme 4: & Oral Sources: Challenges, Opportunities and Techniques. \\
\hline Theme 5: & The Historian's Skills Part 1 \\
\hline Theme 6: & The Historian's Skills Part 2 \\
\hline Theme 7: & The historian's task? \\
\hline Theme 8: & Visual History \\
\hline Theme 9: & Gendered Histories. \\
\hline Theme 10: & Subaltern Histories/History from Below \\
\hline Theme 11: & Class, Labour and Nation \\
\hline Theme 12: & Cultural History/Social History \\
\hline Theme 13: & Comparative Histories \\
\hline Theme 14: & Colonial/Post-colonial History \\
\hline
\end{tabular}

In order to take the experience of the student one level higher and give them even greater insight into the workings of the historian's craft and the discipline itself, we introduced a theoretical and practical component aligned with the theme which focused on "Written documents and working with archives". While the theory would give them an understanding of the archive and its place within the historian's repertoire, the practical component was to take this one step further. Firstly, an archivist would explain and discuss the archival process with the students and then secondly, the students would be given the opportunity of a hands-on project involving the archive. It was believed that this would have the dual purpose of giving them insight into an important dimension of "doing history", but at the same time igniting a passion for what potentially lies ahead of them in terms of research and the primary source domain for possible masters and doctoral study.

An introductory session was developed on the theory and methodology of the archival discipline so as to give the students a basic understanding. This session defines the archives and considers the basic principles of setting up an archive and how one applies these principles to a given collection of records. It also sets out the parameters of the use of an archive as well as the legislation relevant to the domain.

23 A Mlambo, Study guide, Department of Historical and Heritage Studies: Theory and Methodology, GES 713, 2019, pp. 6-7. 
The University archivist begins the theme by defining the concept archive in its broadest sense from a collection of records to a physical structure. The different types of archives are also considered ranging from government to institutional and private. The nature of the archival record and its different formats are addressed. The archive is then compared and contrasted with a library giving the student the opportunity to consider the archive in terms of something they are probably more familiar with. This includes the purpose, the users, the policies, the types of records, their values, organization and retrieval processes. ${ }^{24}$

The next step is to familiarize the students with the archival process and what it is the archivist actually does. Here concepts and methods such as "acquisition and appraisal" as well as "arrangement and description" are unpacked. All of this is explained in the context of the overarching purpose of making the documentation accessible to the potential user. Students are then taken through the process of developing an acquisition policy, the importance of contextual circumstances in determining the relevance and potential of the record. The step by step phases of arrangement entailing a rough macrosort, a detailed micro-sort and then the final sort are illuminated. The criteria that need to be taken into account when compiling an accession register, as well as the process of physically organizing records in order for them to be accessible to potential users, is also expounded upon. Here the importance of provenance and the original order of the documentation is highlighted as being of critical importance in arranging the documentation and the manner in which this is verified is also explained in detail. All of these aspects take the student behind the mere provision of an archive and its documents to be used merely on request.

Finally, in order to indicate the national - and often international importance of the archival process, the various pieces of legislation which pertain to the archival process are highlighted. These include:

- National Archives and Record Services of South Africa Act, Act 43 of 1996

- Promotion to Access of Information Act, Act 2 of 2000

- Protection of Personal Information Act, Act 4 of $2013^{25}$

After the theoretical component of the archive and the archival process have been presented, the students are then given the practical component

24 R van der Merwe, Study guide, Department of Historical and Heritage Studies: Theory and Methodology, GES 713, Archive section, 2019.

25 Constitution of the Archives of the University of Pretoria, 2013, p. 1. 
of the archive theme which entails a group project where they will not only work with archival material in an archive, but will literally "create an archive". ${ }^{26}$ They would be required to work with archival material which had as yet not been accessorized or inventorised - quite literally "virgin" pre-inventorised documentation.

The documentation that the students were tasked to work with emanated from a collection that the University of Pretoria Archive (UPA) acquired in 2013 by default. A collection of documentation which emanated from the Museum of the former Transvaal Education Department was delivered to the University. The unordered documents range from the late nineteenth century and include information regarding the founding of schools, curriculums, lesson plans, newspaper clippings, reports, class and teacher lists, budgets, correspondence between the national and regional departments of education and schools as well as sundry circulars and publications. In an extremely unordered and haphazard manner the documents reflect on the history of the South African education system within the former Transvaal province and are therefore of importance, but also of relevance to the University of Pretoria as a leading educational institution within the region. The potential value of this collection is enhanced in the light of the limited nature of material pertaining to education available in the National Archives Repository. ${ }^{27}$ Thus given the UPA's role as an institutional memory bank of the University of Pretoria, it was proposed (and argued) that the collection be seen as an extension of the collection of tertiary education and should be preserved. This collection of documentation comprises 250 running meters of material and is in dire need of processing. ${ }^{28}$ The documents were boxed in over 350 acid free boxes and stored in a regulated access controlled storage facility.

The project assigned to the students was to deal with these unordered and randomly packed documents. After signing a non-disclosure form the students were put into groups of three and assigned a random box from the collection and given the following task with three components. They needed to complete a worksheet of 10 short questions in order wrap their heads around what was contained in their respective boxes. These related to acquisition and appraisal; preservation; arrangement; description; research potential and accession. Then according to a pro forma example they had

26 KL Harris and R van der Merwe, GES 713 Hand-out 2, 2019.

27 National Archives of South Africa (NASA) Database Selection (available at: www.national.archsrch.gov. za, as accessed September 2019).

$28 \mathrm{R}$ van der Merwe and KL Harris, GES713 Hand-out 1, 2019. 
to carry out a macro-sorting (rough sort), a micro-sorting (detailed sort) and then a final sort where after they were to draw up an accession register for their particular box according to the criteria explained and the example on the template provided. Finally, the students were tasked to prepare a presentation for a colloquium entitled "What's in the Box" regarding what they had discovered in their box addressing the following:

- The historical context

- An overview of the content

- Research potential

- Select one "gem" document for discussion

- Access conditions

In preparing for the colloquium, the students were asked to imagine they were presenting a "newly discovered archive to a press conference and needed to create a hype around this archive to attract potential researchers". ${ }^{29}$ The students thus moved from a theoretical introduction to the archival world, to hands-on involvement with archival material which they had to appraise and order and then compile an accessible inventory. Finally, they had to present their findings at a colloquium where they could share their findings - and what was in their box.

\section{Honours and History}

Reflecting on the "What's in the Box" project we believe that the students were provided with a range of important experiential learning opportunities and real time experiences. Having been literally handed a box of uninventorised and un-sanitised virgin primary archival documentation was probably a daunting, if not overwhelming, experience. Having been tasked to literally create some form of order from ostensible chaos, the students underwent a full circle from being the recipients of a presentation on archives by an archivist, to being archivists themselves and then the presenters on archives at a colloquium. This section reflects on some of the advantages of this project and how the basic ideas and principles can be transformed to other learning environments at both primary and secondary educational levels.

From the outset, the theoretical overview presented by an actual archivist gave the students a tangible connection to an individual (and a profession) that would otherwise remain remote if not removed. This in itself opened up a space of interaction which is generally not accessible.

29 KL Harris and R van der Merwe, GES713 Hand-out 2, 2019. 
Then the archival presentation itself introduced them not only to the concept and meaning of archives, but also the processes involved in the creation of archives. The various phases of a "rough sort, detailed sort and final sort" are made tangibly real as the students have to follow the same process in sorting the content of their respective boxes. In other words, the theory became action. The same applies to the criteria that needed to be taken into account when compiling an accessions register or inventory as they had to transfer what they learnt to actually doing or executing the process. Thus instead of merely studying the process it became a tangible or haptic activity. They moved thus from the world of theory to the world of practice. In a nutshell, the "What's in the Box" experience was one of moving from a sense of KNOWING WHAT to one of KNOWING HOW.

We believe that the success of this component of the course took the students one step further in the making of history and thus exposed them to what could be termed one of the "inner workings" of the historians' profession. This inside look will make the realm of the postgraduate study, where the archive is often a critical component, that much less daunting, while at the same time giving them an inside-out-view of how the institutional archive functions and how it is constructed. It is also believed that the actual experience will both inspire and invigorate the students to want to pursue their studies at master's and later possibly doctoral level. These views were reflected in the presentations done by the students at the Colloquium.

Some reactions reflected on excitement and intrigue: ${ }^{30}$

Archives can hold so much promise and generate great excitement...

Anything could be in the archive box, which makes the mysteries that await one, so exciting...

I imagine that these are the feelings that an archivist experiences...

Others revealed an empathy for the archivist's position: ${ }^{31}$

Another challenge ... was the lack of order or sequence of documents.

Again, we were remined [sic] of the frustration that archivists must experience...

30 D de Caires, T Khumalo, A Harris and M Parker, "Archive's Project - What's in the Box", Department Historical and Heritage Studies Workshop, University of Pretoria, 2019.

31 R McGregor-Langley, B Hansen and C Sanderson, "What's in the Box?", Department Historical and Heritage Studies Workshop, University of Pretoria, 11 June 2019. 
... not only in trying to determine what is important, but how these documents fit into the grand scheme of things.

Lastly, we noticed how difficult it is to determine what is important and what must be discarded. Our own perspectives were called into question, as we sat there and used our own discretion to decide what was interesting and what was not.

It made me think about an important aspect of history. Each historian and archivist have his / her own particular interest in different areas of history and so based on his / her personal circumstances and preferences s/he will have a different category of importance for different documents, which makes the archivist work challenging.

While others revealed a very interesting connectivity with the past they unearthed in the boxes and current issues and contemporary concerns: ${ }^{32}$

... the marginalisation of students with special needs (1970s).

... education as separate but not equal with different approaches for different segments of the population (1960s).

... overcrowding in schools with inadequate facilities (1950s to 1990s).

... marginalization of women and gender discrimination (1950s to 1970s)

As to the research potential the students referred to: ${ }^{33}$

... ideal opportunities for comparative studies.

... new voices and new directions for a more inclusive history.

... the potential of dissident histories, and histories of the marginilised.

By adding this project to the existing GES 713 Honours module it has only further enhanced its purpose of going "beyond the mere gathering of facts and information" and providing the students "with opportunities to apply ... theoretical aspects in practice". 34

Finally, this project aligns with much of what Stephen Aron, Professor of history at the University of California, had to say in an interview on why "primary sources resonate with college students". He believes that primary sources teach students "the craft of history" and in order to train students to be "educated human beings" it is critical to have them "make their own

32 R McGregor-Langley, B Hansen and C Sanderson, "What's in the Box?", Department Historical and Heritage Studies Workshop, University of Pretoria, 2019.

33 C Squire, G Gebhardt and G Hart, "What's in the Box?", Department Historical and Heritage Studies Workshop, University of Pretoria, 2019; D de Caires, T Khumalo, A Harris and M Parker, "Archive's Project - What's in the Box", Department Historical and Heritage Studies Workshop, University of Pretoria, 2019.

34 A Mlambo, Study guide, Department of Historical and Heritage Studies: Theory and Methodology, GES 713, 2019, pp. 6-7. 
discoveries and learn the craft of history". ${ }^{35}$ This project does exactly that, but goes even further than Aron indicates in allowing and encouraging the students to be an actual part of the creation of an archival process. Aron also claims that the "skill" is more important than the "content". He also contends that there is for him a difference between having students learn history and learning the craft of historians. In order to turn them into historians, they need to discover for themselves and not have information handed to them. They need to find for themselves the stuff of history as opposed to being merely passive consumers of it. ${ }^{36}$ Here this project not only complies with these beliefs, but again takes them one step further allowing the student to deal with the remnants of the past (primary documentary material), sort and order the information (accessorise and inventorise) and then consider the material's potential contribution (contextualize and relevance).

As a postscript, it is believed that although the DHHS is ideally positioned for the implementation of this strategy given the access to the UP Archives as well as the availability of an un-inventorised archival collection, it could be implemented in other contexts across the primary and secondary educational spectrum. Depending on the grade level, educators could develop their "own archival boxes" and adapt questions for learners to discover the history that is "in the box".

\section{References}

Aron S 2018. “Teaching students the craft of history”. Available at https://www.youtube. com/watch?v=UCXpOtqxA30. Accessed August 2019.

Behr, C and Nevin, S 2018. "The Roehampton Campus Project: Using campus, collections and memories of the university as a learning and teaching resource for Humanities students", Arts and Humanities in Higher Education, 1(18):1-21.

Black, J and DM 2000. MacRaild, Studying History, 2. New York: Palgrave.

Constitution of the Archives of the University of Pretoria, 2013.

De Caires, D, Khumalo, T, Harris, A and Parker, M 2019. Archive's Project - What's in the Box. Department Historical and Heritage Studies Workshop, University of Pretoria.

35 S Aron, "Teaching students the craft of history" (available at: https:/www.eradex.com/videos/teachingstudents-craft-history-conversation-professor-stephen-aron, as accessed August 2019).

36 S Aron, "Teaching students the craft of history" (available at: https:/www.eradex.com/videos/teachingstudents-craft-history-conversation-professor-stephen-aron, as accessed August 2019). 
Elton, GR 1987. The Practice of History. London, Fontana Press.

Evans, RJ 2000. In defence of History. London, Granta Books.

Harris, KL 2019. Study guide, Department of Historical and Heritage Studies: Africa and South Africa - An Overview, GES 120:1-38.

Harris, KL and Van der Merwe, R 2019. GES713 Hand-out 2.

Haydn, T (et al) 1997. Learning to teach History in secondary school. London, Routledge.

Jackdaws Publications, 2014. Available at https://www.jackdaw.com/t-jackdaws.aspx. Accessed January 2020.

Jenkins, K 1995. What is History? London, Routledge.

Manyane, RM 1999. "History teaching in South Africa within the context of the human and social sciences", PhD Education, Unisa.

McGregor-Langley, R, Hansen, B and Sanderson, C 2019. "What's in the Box?". Department Historical and Heritage Studies Workshop, University of Pretoria.

Mlambo, A 2019. Study guide, Department of Historical and Heritage Studies: Theory and Methodology, GES 713:1-25.

Momigliano, A 1983. The introduction of teaching History as an academic subject and its implications", Minerva, 21(1):1-15.

Moran, D 2016. How history should be taught: Connections to the present. Palo Alto Online, 16 January 2016. Available at: file://C:/Users/u02549085/Downloads/ How $\% 20$ history $\% 20$ should $\% 20$ be $\% 20$ taught_\%20Connections $\% 20$ to $\% 20$ the $\% 20$ present $\% 20 \_\% 20$ A $\% 20$ Pragmatist's $\% 20$ Take $\% 20 \_\% 20$ Douglas\%20Moran\%20_\%20Palo\%20Alto\%20Online\%20_\%20(2).pdf. Accessed August 2019.

National Archives of South Africa (NASA) 2019. Database selection. Available at: www. national.archsrch.gov.za. Accessed September 2019.

Squire, C, Gebhardt, G and Hart, G 2019. What's in the Box?. Department Historical and Heritage Studies Workshop, University of Pretoria.

Study International Staff, Should we rethink how history is taught in schools?, SI News, 17 May 2019. Available at: https://www.studyinternational.com/news/shouldwe-rethink-how-history-is-taught-in-schools/. Accessed August 2019. 
Teaching strategies: Experiential learning and field work. Centre for Research and Learning, University of Michigan. Available at: http://www.crlt.umich.edu/ programs. Accessed January 2020.

Van der Merwe, R 2019. Study guide, Department of Historical and Heritage Studies: Archives, GES 713:1-13.

Van der Merwe, R and Harris, KL 2019. GES713 Hand-out 1.

Wassermann, J 2011. Learning about controversial issues in school History: The experiences of learners in KwaZulu-Natal Schools. Journal of Natal and Zulu History, 29(1):131-157.

Wood, RGE 1971. Archive units for teaching. Teaching History, 2(6):158-165.

Woolf, D 2005. Historiography. In: MC Horowitz (ed), New dictionary of the |History of ideas, 1. New York, Scribners.

Woolf, D 2019. A concise history of History: Global historiography from antiquity to the present. Cambridge, Cambridge University Press. 